\title{
BAHAN AJAR MENULIS TEKS PROSEDUR BERBASIS KITAB SAFINATUN NAJAH DI LINGKUNGAN PESANTREN
}

\author{
Alivia Nadatul Ais yi, Arju Muti'ah, dan Bambang Edi Purnomo \\ Program Studi Pendidikan Bahasa dan Sastra Indonesia, Jurusan Pendidikan Bahasa dan Seni \\ Fakultas Keguruan dan Ilmu Pendidikan, Universitas Jember \\ Jalan Kalimantan No. 37, Jember, Jawa Timur, 68121 \\ Surel: alivianadatulaisyi@gmail.com
}

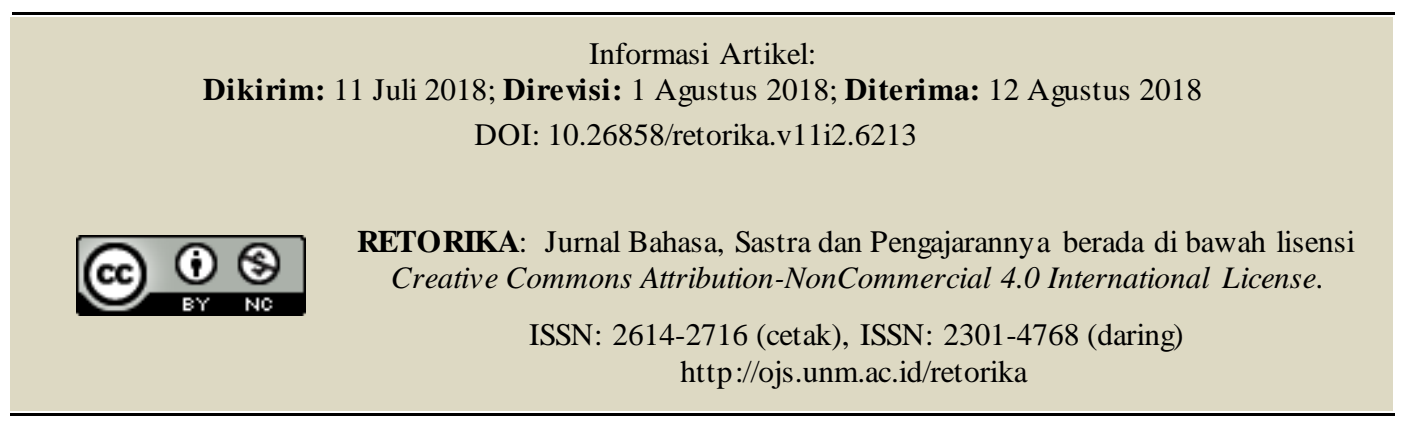

\begin{abstract}
Instructional Material Result in Writing a Procedure Text Based on Kitab Safinatun Najah in Pesantren. The research and development of this instructional material results in a product in the form of a procedure text module based on Safinatun Najah. This research and development model used the 4D model which is modified into define, design, and develop. The development of this instructional material was based on the 2013 Curriculum through the scientific approach. The result categorizes the module as a highly appropriate module with an average validity score of $91,7 \%$. The implementation of the instructional material was conducted in two meetings. The results of the study obtained practical score of $95 \%$ and $98 \%$. The response's result toward the module obtained an average score of $89 \%$. The result indicates that instructional material is appropriate to apply.
\end{abstract}

\begin{abstract}
Abstrak. Bahan Ajar Menulis Teks Prosedur Berbasis Kitab Safinatun Najah di Lingkungan Pesantren. Penelitian dan pengembangan bahan ajar ini menghasilkan produk berupa Modul Teks Prosedur Berbasis Kitab Safinatun Najah. Model penelitian dan pengembangan yang digunakan adalah model 4D yang dimodifikasi menjadi define, design, dan develop. Bahan ajar ini dikembangan berdasarkan Kurikulum 2013 dengan pendekatan saintifik. Berdasarkan hasil uji validitas diketahui bahwa modul yang dihasilkan berkategori sangat layak dengan validitas ratarata $91,7 \%$. Hasil penerapan modul memperoleh nilai $95 \%$ dan $98 \%$. Hasil respon siswa terhadap modul memperoleh nilai rata-rata persentase $89 \%$. Perolehan hasil tersebut menunjukkan bahwa bahan ajar yang dihasilkan berkategori sangat layak untuk diterapkan.
\end{abstract}

Kata kunci: bahan ajar, menulis, penelitian dan pengembangan, teks prosedur 
Kurikulim 2013 menegaskan bahwa Bahasa Indonesia berperan sebagai penghela ilmu pengetahuan. Bahasa Indonesia memudahkan siswa untuk mempelajari berbagai bidang ilmu lainnya. Berdasarkan hal tersebut, pembelajaran bahasa Indonesia berbasis teks dirancang sebagai bagian dari Kurikulum 2013. Berbagai jenis teks yang diajarkan di tingkat Sekolah Dasar, Sekolah Menengah Pertama, Sekolah Menengah Atas sampai Perguruan Tinggi dimuat dalam Kurikulum 2013 (Mahsun, 2014:94). Hal ini sesuai dengan tujuan pembelajaran bahasa Indonesia berbasis teks, yaitu agar siswa mampu memahami dan memproduksi teks secara mandiri. Pembelajaran diawali dengan memberikan pemodelan, kemudian siswa bekerja sama untuk mengembangkan teks.

Pembelajarn bahasa Indonesia di sekolah menengah pertama menyajikan berbagai jenis teks. Salah satu di antaranya adalah teks prosedur. Tujuan pembelajaran berbasis teks ialah siswa mampu memahami dan menggunakan teks sesuai dengan tujuan sosial teks yang dipelajarinya (Mahsun, 2014:212). Tujuan sosial teks prosedur adalah agar siswa dapat melakukan kegiatan dalam kehidupan sehari-hari sesuai dengan kebutuhan. Melalui kegiatan pemahaman tersebut siswa diharapkan mampu memproduksi atau mengembangkan teks prosedur secara mandiri melalui pembelajaran bahasa Indonesia.

Pembelajaran menulis teks prosedur untuk SMP disajikan pada kelas VII Semester Ganjil. Kompetensi yang diajarkan adalah menelaah struktur dan aspek kebahasaan teks prosedur tentang cara melakukan sesuatu dan cara membuat (cara memainkan alat musik/tarian daerah, cara membuat kuliner khas daerah, dll.) dari berbagai sumber yang dibaca dan didengar (butir 3.6) dan menyajikan data rangkaian kegiatan ke dalam bentuk teks prosedur (tentang cara memainkan alat musik daerah, tarian daerah, cara membuat cinderamata, dll) dengan memperhatikan struktur, unsur kebahasaan, dan isi secara lisan dan tulis (butir 4.6). Berdasarkan kompetensi dasar 3.6 dan 4.6 peserta didik diharapkan mampu memahami struktur dan kebahasaan teks prosedur kemudian mampu menyajikan data rangkaian kegiatan ke dalam bentuk teks prosedur dengan memperhatikan struktur, unsur kebahasaan, dan isi sehingga tujuan akhirnya adalah peserta didik dapat mengembangkan atau menuliskan teks prosedur secara mandiri dapat tercapai.

Kedua kompetensi dasar yang telah dikemukakan diajarkan dengan memperhatikan kon- disi lingkungan dan kebutuhan siswa. Perhatian terhadap kondisi lingkungan dan kebutuhan siswa dapat diakomodasi melalui penerapan pendekatan kontekstual. Trianto (2008:10) menyatakan bahwa pendekatan kontekstual adalah konsep belajar yang mengaitkan materi yang diajarkan dengan situasi nyata siswa dan mendorong siswa untuk membuat hubungan antara pengetahuan yang dimiliki dengan penerapan dalam kehidupan sehari-hari.

Salah satu usaha untuk mencapai pembelajaran berdasarkan pendekatan kontekstual adalah memperhatikan lingkungan siswa. Sekolah di bawah naungan pondok pesantren memiliki ciri kondisi lingkungan dan kebutuhan siswa yang khas. Hasan, dkk. (2016:3) mengatakan bahwa pendidikan pesantren memiliki ciri dan karakter yang berbeda. Diharapkan siswa yang berada di bawah naungan lembaga pondok pesantren dapat melakukan proses pembelajaran berdasarkan lingkungannya sehingga pembelajaran akan lebih bermakna. Materi pembelajaran yang sesuai dengan konteks lingkungan akan menumbuhkan kebermaknaan dalam proses pembelajaran.

Pelajaran agama yang diperoleh secara intensif dapat dijadikan sebagai sarana untuk meningkatkan kemampuan siswa dalam memahami materi pembelajaran Bahasa Indonesia yang sesuai dengan kebutuhan siswa. Upaya untuk meningkatkan pemahaman dan kemampuan mempraktikkan materi pelajaran Bahasa Indonesia siswa yang berada di pesantren dapat dilakukan dengan berbagai cara, seperti memberikan materi pembelajaran yang berkaitan dengan pembelajaran di madrasah diniyah atau muatan lokal pesantren. Salah satu ciri khas mata pelajaran muatan lokal pada pondok pesantren adalah fikih. Fikih merupakan salah satu pelajaran keagamaan yang membahas tentang tatacara beribadah menurut Islam, seperti cara berwudu, cara menyucikan najis, cara memandikan jenazah, dan lain sebagainya.

Pembelajaran yang memadukan materi bahasa Indonesia dengan muatan lokal dipandang cocok untuk dimanfaatkan sebagai salah satu sumber belajar yang baik sehingga dapat digunakan sebagai suplemen bahan ajar dalam pembelajaran teks prosedur. Melalui pembelajaran menulis teks prosedur tersebut, siswa diharapkan semakin memahami materi pembelajaran bahasa Indonesia sekaligus muatan lokal pelajaran fikih.

SMP Nuris adalah salah satu lembaga di bawah naungan Yayasan Pondok Pesantren Nuris 
Jember. Pembelajaran muatan lokal atau madrasah diniyah pada pesantren tersebut membahas kajian fikih. Kitab fikih yang digunakan adalah Kitab Safinatun Najah. Kitab tersebut adalah kitab karangan Syekh Salim bin Samir al-Hadrami. Kitab ini merupakan kitab yang khusus membahas ibadah, mulai dari cara bersuci sampai puasa. Kitab ini sangat mudah dipaham karena penjelasannya yang lebih sederhana sehingga banyak pesantren di Indonesia baik salaf ataupun modern yang mengkaji kitab ini. Oleh sebab itu, dipandang sesuai untuk menghubungkan dengan pembelajaran di sekolah khususnya pelajaran Bahasa Indonesia yang disesuaikan dengan $\mathrm{KD}$ menulis teks prosedur tersebut.

Pembelajaran yang memadukan pembelajaran di sekolah dengan pelajaran muatan lokal tersebut dipandang perlu karena diperkuat dengan studi pendahuluan di SMP Nuris Jember. Melalui studi pendahuluan, penulis menemukan informasi yang diperoleh melalui proses wawancara kepada guru Bahasa Indonesia kelas VII SMP Nuris bahwa pembelajaran menulis teks prosedur belum berlangsung secara maksimal. Temuan penulis menunjukkan bahwa salah satu faktor yang sangat mempengaruhi adalah ketersediaan bahan ajar yang kurang relevan dengan kebutuhan lingkungan pembelajaran. Pendidik berharap dengan menggunakan bahan ajar yang sesuai dengan konteks lingkungan kompetensi siswa dapat meningkat.

Berdasarkan uraian di atas, dipandang perlu untuk melakukan pengembangan bahan ajar pada materi menulis teks prosedur. Pengembangan bahan ajar menulis teks prosedur tidak dapat terlepas dari tujuan pembelajaran menulis teks prosedur butir 3.5 dan 4.5 , yakni mengidentifikasi dan menyimpulkan teks prosedur.

Bahan ajar menulis teks prosedur yang dikembangkan berbasis Kitab Safinatun Najah disesuaikan dengan konteks pembelajaran di lingkungan pondok pesantren. Pada lingkungan pesantren, siswa/santri dituntut untuk menguasai tata cara ibadah dengan benar. Kompetensi tersebut berkaitan dengan teks prosedur. Siswa diharapkan dapat menguasai kompetensi tersebut dan menyalurkan ilmu praktik ibadah yang telah diperoleh kepada masyarakat.

Hasil-hasil penelitian pengembangan bahan ajar menulis teks prosedur menunjukkan keefektifan. Sorraya (2014) menemukan bahwa pengembangan modul menulis teks prosedur sebagai suplemen bahan ajar untuk siswa kelas $\mathrm{X}$
SMK dapat meningkatkan keterampilan menulis teks prosedur siswa. Kurniasari (2015) membahas tentang pengembangan modul menulis teks prosedur kompleks untuk siswa kelas X SMA menunjukkan hasil yang efektif: modul dapat diimplementasikan dengan memperoleh nilai kelayakan yang memuaskan. Penelitian Saleh dan Sultan (2015) yang mengembangkan bahan ajar teks prosedur dengan struktur (1) judul, (2) pengantar, (3) pemahaman konsep, (4) pemodelan, (5) analisis teks, dan (6) integrasi nilai karakter menunjukkan bahwa kepraktisan dan keefektifan dalam meningkatkan hasil belajar siswa. Al'aliyah (2016) menemukan bahwa pengembangan bahan ajar berupa media untuk meningkatkan kemampuan menulis teks prosedur siswa dapat digunakan dengan efektif.

Berbeda dengan penelitian yang telah dipaparkan, penelitian pengembangan bahan ajar menulis teks prosedur ini berbasis Kitab Safinatun Najah untuk digunakan di lingkungan pesantren. Bahan ajar dikemas dalam bentuk modul yang dapat digunakan siswa untuk belajar secara mandiri dengan atau tanpa bimbingan guru. Menurut Susilo, dkk. (2016:51), modul adalah bahan ajar cetak yang di di dalamnya berisi materi ajar dan dapat digunakan secara mandiri. Modul disusun dengan beroerientasi pada aktivitas. Hal tersebut sejalan dengan Kurikulum 2013 yang menyarankan pendekatan saintifik. Modul yang dikembangkan berisi dua kegiatan pembelajaran, yakni berkenalan dengan teks prosedur dan berlatih menulis teks prosedur.

Penelitian ini bertujuan mendeskripsikan (1) profil bahan ajar menulis teks prosedur berbasis Kitab Safinatun Najah untuk siswa kelas VII SMP/MTS di lingkungan pesantren, (2) hasil validitas bahan ajar menulis teks prosedur berbasis kitab Safinatun Najah untuk siswa kelas VII SMP/MTS di lingkungan pesantren, (3) penerapan bahan ajar menulis teks prosedur berbasis kitab Safinatun Najah di kelas VII SMP/MTS di lingkungan pesantren, dan (4) hasil respon siswa VII SMP Nuris Jember terhadap bahan ajar menulis teks prosedur berbasis Kitab Safinatun $\mathrm{Na}$ jah untuk kelas VII SMP/MTS di lingkungan pesantren.

\section{METODE}

Penelitian dan pengembangan ini menggunakan model 4-D (Four-D Models) yang dimodi- 
fikasi. Model 4-D, meliputi tahap define, design, development and disseminate (Thiagarajan, Semmel, dan Semmel, 1974:5). Penelitian pengembangan yang dilakukan hanya terbatas sampai tahap mengembangkan atau development karena mempertimbangkan keterbatasan waktu dan faktor keterbatasan objek penelitian yang ditentukan. Diseminasi lebih fokus penyebarluasan produk hasil penelitian (Rapi Tang, Jufri, dan Sultan, 2015).

Tahapan yang dilakukan pada penelitian ini diuraikan sebagai berikut. Pertama, tahap define atau pendefinisian merupakan proses menetapkan kebutuhan dalam kegiatan pembelajaran. Penetapan kebutuhan dilakukan dengan memperhatikan kesesuaian kebutuhan pembelajaran dengan kurikulum yang berlaku, tingkat perkembangan siswa, dan kondisi sekolah. Kedua, tahap design atau perancangan bertujuan untuk merancang bahan ajar menulis teks prosedur berbasis Kitab Safinatun Najah yang digunakan pada pembelajaran Bahasa Indonesia kelas VII SMP/ MTS di lingkungan pesantren. Pada proses perancangan dilakukan rekonstruksi teks dari Kitab $\mathrm{Sa}$ finatun Najah menjadi teks prosedur yang digunakan sebagai teks pemodelan pada modul yang dikembangkan. Ketiga, tahap develop atau pengembangan betujuan untuk menghasilkan modul bahan ajar berdasarkan masukan dari validator ahli dan validator praktisi.

Proses validasi bertujuan untuk menilai validitas modul bahan ajar yang dikembangkan sebelum dilakukan uji coba. Hasil validasi digunakan untuk melakukan revisi produk awal. Bahan ajar ini divalidasi oleh (1) ahli pembelajaran bahasa dan sastra Indonesia, (2) ahli bahasa, (3) ahli Kitab Safinatun Najah, (4) ahli kegrafikaan, dan (5) praktisi guru bahasa Indonesia. Hasil evaluasi dari validator digunakan sebagai dasar perbaikan dan penyempurnaan produk yang dikembangkan. Setelah draf I divalidasi dan direvisi, dihasilkan draf II yang selanjutnya diujikan kepada siswa dengan uji coba lapangan terbatas. Uji coba produk lapangan terbatas dilakukan pada siswa kelas VII Sains SMP Nuris sesuai dengan keputusan kepala sekolah untuk melakukan uji coba pada kelas tersebut. Hasil yang diperoleh pada tahap ini adalah modul bahan ajar yang telah direvisi.

Penerapan bahan ajar dilakukan pada siswa kelas VII Sains SMP Nuris Jember. Kegiatan uji coba ini ditujukan untuk memperoleh persentase kelayakan penggunaan bahan ajar dengan cara melaksanakan kegiatan pembelajaran. Kegiatan pembelajaran dilakukan oleh peneliti sebagai guru model didampingi guru Bahasa Indonesia kelas VII sebagai observer untuk mengamati aktivitas siswa dan guru selama proses pembelajaran berlangsung. Sebelum proses pembelajaran, peneliti memberikan lembar observasi kepada guru observer untuk menilai aktivitas siswa dan guru model (peneliti) sesuai dengan prosesnya.

Proses penerapan dilakukan oleh guru dengan mengajarkan materi yang terdapat dalam pembelajaran unit satu terkait memahami struktur dan kaidah kebahasaan teks prosedur. Siswa berjumlah 25 dan seluruh siswa mendapat modul suplemen pembelajaran yang diuji coba. Setelah kegiatan pembelajaran selesai, siswa mencoba mengerjakan latihan untuk memantapkan pemahaman dan merespon refleksi yang terdapat di dalam modul siswa.

Setelah itu, guru mengajarkan materi yang terdapat dalam pembelajaran Unit dua terkait menulis teks prosedur. Setelah kegiatan pembelajaran selesai, siswa diajak oleh guru untuk mengerjakan uji kompetensi, merespon kolom refleksi yang terdapat dalam modul, dan menyelesaikan tugas menulis teks prosedur.

Data dalam penelitian dan pengembangan ini terbagi menjadi tiga, yakni data verbal, data nonverbal, dan data numeral. Data verbal terdiri atas data tertulis dan lisan. Data verbal tetulis meliputi, (1) hasil validasi dari para ahli dan praktisi dan (2) komentar dan saran validator terhadap hasil uji coba lapangan. Sementara itu, data verbal lisan berupa hasil wawancara dengan guru Bahasa Indonesia. Data nonverbal berupa gambar peristiwa yang relevan terkait dengan materi bahan ajar. Data numeral berupa (1) angka persentase hasil validasi, (2) angka persentase hasil observasi, dan (3) angka persentase hasil uji cba.

Sumber data dalam penelitian dan pengembangan ini adalah (1) validator ahli dan praktisi, (2) guru bahasa Indonesia, (3) siswa kelas VII SMP Nuris Jember, dan (4) peristiwa pembelajaran pada proses penerapan bahan ajar.

Data verbal dan nonverbal dalam penelitian ini dianalisis secara deskriptif. Data numeral diolah dengan menggunakan digunakan analisis kuantitatif pada data yang diperoleh dari lembar validasi ahli, lembar validasi praktisi, dan lembar uji coba produk pada respon siswa. Data yang didapatkan dari lembar validasi dianalisis dengan rumus dan konversi tingkat skala 4 Arikunto (2002:244). Pedoman interpretasi be- 
serta kriteria kelayakan produk ditunjukkan pada Tabel 1.

Tabel 1. Kriteria Kelayakan Produk

\begin{tabular}{ccc}
\hline Persentase & Kualifikasi & $\begin{array}{c}\text { Tindak } \\
\text { Lanjut }\end{array}$ \\
\hline $85 \%-100 \%$ & Sangat layak & Implementasi \\
$75 \%-84 \%$ & Layak & Implementasi \\
$55 \%-74 \%$ & Cukup layak & Revisi \\
$<55 \%$ & Kurang layak & Diganti \\
\hline
\end{tabular}

\section{HASIL DAN PEMBAHASAN}

\section{Hasil}

Paparan hasil penelitian ini dikemukakan menjadi empat bagian, yakni (1) profil bahan ajar menulis, (2) validitas bahan ajar, (3) penerapan bahan ajar, dan (4) respon penggunaan bahan ajar.

\section{Profil Bahan Ajar}

Profil bahan ajar mencakup dua hal, yakni bentuk dan sistematika modul. Modul Suplemen Pembelajaran Menulis Teks Prosedur Berbasis Kitab Safinatun Najah untuk Siswa Kelas VII SMP/MTS dibuat untuk mengajarkan satu materi yang spesifik supaya peserta belajar mencapai kompetensi tertentu.

Struktur modul dibagi menjadi tiga bagian utama, yakni bagian pembuka, inti, dan penutup. Bagian pembuka mencakup enam aspek berupa: (a) halaman judul, (b) halaman hak cipta, (c) kata pengantar, (d) petunjuk penggunaan modul, (e) daftar tujuan kompetensi, dan (f) daftar isi. Penjelasan setiap bagian pembuka modul diuraikan sebagai berikut.

Pertama, judul. Judul memuat gambaran umum isi dari modul. Pada sampul terdapat nama penulis, yakni Alivia Nadatul Aisyi. Judul modul; Modul Suplemen Menulis Teks Prosedur Berbasis Kitab Safinatun Najah, tingkat satuan pendidikan yang dituju yakni untuk Sekolah Menengah Pertama (SMP) atau Madrasah Tsanawiyah (MTS), penerbit pada modul ini penerbit adalah FKIP Universitas Jember, dan identitas kurikulum yang digunakan pada modul, yakni Kurikulum 2013.

Kedua, halaman hak cipta. Halaman hak cipta merupakan bagian dari modul yang memuat informasi mengenai modul. Halaman hak cipta berfungsi untuk memudahkan pendataan modul. Pada bagian ini terdapat nama penulis, penata le- tak, pendesain sampul, ukuran buku, tahun diterbitkan, dan katalog modul.

Ketiga, ucapan terima kasih. Halaman ini berisi ucapan terimakasih atas terselesaikannya modul, alasan penulisan modul, dan manfaat yang bisa diperoleh dengan membaca modul tersebut.

Keempat, petunjuk penggunaan.Petunjuk penggunaan modul berisi beberapa informasi yang harus dilakukan siswa ketika menggunakan modul. Penjelasan petunjuk bagian inti diperkuat dengan gambar dari bagian-bagian inti tersebut. Petunjuk penggunaan akan mempermudah pemakai modul untuk kegiatan pembelajaran.

Kelima, daftar kompetensi. Daftar kompetensi memuat kompetensi yang digunakan pada modul.

Keenam, daftar isi. Daftar isi merupakan halaman yang menginformasikan kepada pembaca tentang topik-topik yang ditampilkan dalam modul sesuai urutan tampilan/halaman.

Bagian inti memuat isi materi pembelajaran. Bagian ini mencakup: (a) peta pembelajaran, (b) pendahuluan atau tinjauan umum, (c) uraian materi, (d) penugasan, (e) refleksi diri, dan (f) rangkuman. Peta pembelajaran dalam modul ini memuat dua unit. Unit satu, menelaah teks prosedur yang terdiri dari empat kegiatan: (1) mencermati struktur teks prosedur; (2) memperbaiki dan melengkapi teks prosedur; (3) menelaah penggunaan bahasa pada teks prosedur; dan (4) menyimpulkan konsep teks prosedur. Unit dua, mari menulis teks prosedur yang terdiri dari empat kegiatan: (1) menyusun dan mengembangkan teks prosedur; (2) menulis teks prosedur; (3) mengoreksi ejaan, tanda baca, dan aspek kebahasaan teks prosedur; dan (4) mempraktikkan isi teks prosedur.

Setiap bagian inti tersebut diuraikan sebagai berikut. Pertama, pendahuluan. Pendahuluan pada modul ini berupa pembuka unit. Pada pembuka unit terdapat tujuan pembelajaran. Tujuan berfungsi untuk menyampaikan target pembelajaran sebelum kegiatan dimulai.

Kedua, uraian materi. Uraian materi berisi penjelasan yang akan dilakukan selama proses kegiatan pembelajaran. Materi disajikan berdasarkan kompetensi yang digunakan. Pada uraian materi terdapat teks pemodelan yang berjudul Tata Cara Berwudu, Tata Cara Melakukan Salat Jenazah, Tata Cara Menyucikan Najis Mughalladah, dan Tata Cara Memandikan Jenazah. Materi terbagi menjadi dua unit, unit satu untuk 
memahami konsep struktur dan kebahasan teks prosedur dan unit dua berisi proses untuk menulis teks prosedur. Uraian materi dikonsep berdasarkan pendekatan saintifik. Siswa diajak untuk melakukan rangkaian kegiatan pembelajaran dengan latihan. Latihan tersebut dimaksudkan untuk memantapkan materi yang dipelajari siswa sehingga pembelajaran akan lebih bermakna.

Setiap unit terdapat empat kegiatan. Unit satu, siswa mempelajari materi pengetahuan teks prosedur. Kegiatan pertama, siswa membaca sebuah teks prosedur dan menentukan strukturnya berdasarkan panduan. Kemudian, siswa berlatih mengisi kolom kosong tentang struktur teks prosedur. Latihan ini dimaksudkan untuk memantapkan pemahaman siswa. kegiatan kedua, siswa memperbaiki dan melengkapi sebuah teks prosedur. Kegiatan tiga, siswa mempelajari tentang kebahasaan teks prosedur, dilanjutkan dengan latihan untuk memantapkan pemahaman siswa. Kegiatan terakhir menyimpulkan konsep teks prosedur. Siswa diberi beberapa kalimat pernyataan tentang teks prosedur, kemudian menentukan benar atau salah isi pernyataan tersebut. Unit satu diakhiri dengan kegiatan latihan untuk memantapkan pemahaman.

Unit kedua, siswa mempelajari materi keterampilan teks prosedur. Kegiatan pertama, siswa membuat kerangka teks prosedur berdasarkan strukturnya. Kemudian, siswa menuliskan teks prosedur. Kegiatan ketiga, siswa mengoreksi ejaan tanda baca dan aspek kebahasaan. Kegiatan keempat siswa memperaktikkan teks prosedur untuk membuktikan kebergunaan teks prosedur yang telah dibuat. Selanjutnya, pada akhir kegiatan siswa diharapkan mampu menulis sebuah teks prosedur secara mandiri, dilanjutkan dengan uji kompetensi sebagai penilaian akhir. Pada akhir kegiatan pembelajaran, siswa mengevaluasi hasi karya teman sejawatnya menggunakan pedoman penilaian yang telah terdapat dalam modul.

Ketiga, penugasan. Pada modul ini terdapat dua jenis penugasan. Pertama, penugasan sebagai bentuk latihan untuk meningkatkan kemampuan siswa yang terdapat pada akhir setiap unit. Penugasan ini, dilakukan secara berkelompok dan mandiri. Penugasan kedua untuk mengevaluasi kemampuan siswa secara mandiri. Penugasan ini diberikan pada akhir pembelajaran yang berupa pilihan objektif dan uraian. Pada tes pilihan objektif, siswa menjawab soal dengan memberi tanda silang pada jawaban yang paling benar. Siswa menganalisis struktur dan kebahasaan teks prosedur yang disajikan uraian.

Keempat, refleksi diri. Refleksi diri berfungsi sebagai tindak lanjut untuk mengevaluasi pemahaman siswa terhadap materi yang dipelajari. Pada modul ini terdapat dua refleksi diri yang terdapat di akhir setiap unit. Refleksi pertama untuk mengajak siswa mengukur sendiri pemahaman tentang struktur dan kebahasaan teks prosedur. Refleksi kedua untuk mengukur kemampuan siswa pada keterampilan menulis dan menyunting teks prosedur.

Kelima, rangkuman. Rangkuman berisi ringkasan materi pembelajaran. Bagian ini memuat seluruh materi pembejaran secara garis besar. Tujuan dari rangkuman agar siswa memiliki pemahaman garis besar pembelajaran pada modul. Ketersediaan rangkuman mampu memudahkan siswa untuk memahami materi pembelajaran.

Bagian penutup, meliputi tiga aspek: (a) glosarium, (b) kunci jawaban, (c) daftar pustaka, dan (d) riwayat penulis. Glosarium berfungsi untuk memudahkan siswa dalam memahami kosa kata. Daftar pustaka pada modul ini berisi daftar sumber yang dijadikan rujukan untuk mengembangkan modul. Terdapat pula daftar rujukan gambar, yang berasal dari koleksi pribadi penulis.

Kunci jawaban memuat jawaban-jawaban dari pertanyaan atau soal-soal yang digunakan untuk menguji penugasan materi siswa, baik untuk penugasan latihan maupun evaluasi. Siswa dapat melihat jawaban benar setelah mengerjakan evaluasi akhir. Pada modul ini terdapat dua bagian kunci jawaban. Kunci jawaban untuk latihan kegiatan dan untuk evaluasi pada uji kompetensi di akhir pembelajaran.

Riwayat penulis menjelaskan seputar biografi atau profil dari penulis modul. Modul ini menggunakan istilah profil penulis. Profil penulis dalam modul ini, menjelaskan tentang riwayat pendidikan, pengalaman dan organisasi penulis secara mendetail. Profil memuat narahubung untuk memudahkan menghubungi penulis.

\section{Validitas Bahan Ajar}

Validitas bahan ajar mencakup: (1) validitas isi dan konstruk bahan ajar, (2) validitas penyajian bahan ajar, (3) validitas kebahasaan bahan ajar, dan (4) validitas kegrafikaan. Uraian hasil uji validitas tersebut tersebut dipaparkan pada bagian berikut itu. 


\section{Validitas Isi dan Konstruk Bahan Ajar}

Validitas isi dan validitas konstruk dimaksudkan untuk memperoleh nilai kelayakan dari segi substansi isi dan konstruk. Validasi dilakukan oleh tiga validator, yaitu (1) validator ahli isi pembelajaran (VA1), (2) validator ahli konstruk Kitab Safinatun Najah (VA3), dan (3) validator praktisi guru bahasa Indonesia (V5/VP). Validasi isi mencakup aspek, yakni: (a) keakuratan materi, (b) kelengkapan materi, dan (c) kesesuaian materi. Validasi konstruk materi Kitab Safinatun Najah menilai terkait tiga aspek, yakni: (a) keakuratan teori kitab Safinatun Najah, (b) keautentikan materi Kitab Safinatun Najah yang disajikan di dalam bahan ajar, serta (c) kebermaknaan dan kemenarikan materi Kitab Safinatun Najah yang disajikan dalam bahan ajar. Validasi isi dan konstruk yang dilakukan menghasilkan persentase sebagaimana pada Tabel 1 .

Jumlah penilaian validator ahli (VA1 dan VA3) dan validator praktisi (V5/VP) per aspek penilaian $\left(\sum x\right)$ adalah 89 , sedangkan jumlah skor maksimal per aspek penilaian adalah 100. Hubungan antara kedua aspek (skor validasi dan skor maksimal) tersebut berfungsi untuk menentukan persentase kelayakan (P). Berdasarkan hasil hitung rata-rata dari validitas substansi isi dan konstruk bahan ajar didapatkan persentase kelayakan bahan ajar sebesar $89 \%$. Apabila dihubungkan dengan kriteria yang telah ditetapkan, maka persentase tersebut menunjukkan bahwa kualifikasi bahan ajar dari segi substansi isi dan konstruk berkategori layak.

\section{Validitas Penyajian Bahan Ajar}

Validitas penyajian dilakukan oleh validator ahli pembelajaran (VA1) dan validator praktisi guru Bahasa Indonesia (V5/VP). Validasi penyajian bahan ajar mencakup sistematika penyajian dan penyajian pembelajaran (Tabel2).
Tabel 2. Validitas Penyajian Bahan Ajar

\begin{tabular}{|c|c|c|c|c|c|c|}
\hline \multirow[t]{2}{*}{ No. } & \multirow{2}{*}{$\begin{array}{l}\text { Aspek } \\
\text { Penilaian }\end{array}$} & \multicolumn{2}{|c|}{ Validator } & \multirow[b]{2}{*}{$X$} & \multirow[b]{2}{*}{$X i$} & \multirow[b]{2}{*}{$\mathrm{Pi}$} \\
\hline & & VA1 & VP & & & \\
\hline 1 & $\begin{array}{l}\text { Sistematika } \\
\text { Penyajian }\end{array}$ & 6 & 8 & 14 & 16 & $87,5 \%$ \\
\hline 2 & $\begin{array}{l}\text { Penyajian } \\
\text { Pembelajaran }\end{array}$ & 9 & 16 & 25 & 32 & $78 \%$ \\
\hline
\end{tabular}

Jumlah jawaban per aspek penilaian $\left(\sum \mathrm{x}\right)$ adalah 39, sedangkan jumlah skor maksimal per aspek penilaian adalah 48 . Berdasarkan hasil hitung, diperoleh rata-rata validitas penyajian bahan ajar sebesar $81 \%$. Persentase tersebut menunjukkan bahwa kualifikasi bahan ajar dari segi penyajian berkategori sangat layak.

\section{Validitas Kebahasaan Bahan Ajar}

Validitas kebahasaan dilakukan oleh validator ahli kebahasaan (VA2) dan praktisi pembelajaran bahasa Indonesia (V5/VP). Validasi kebahasaan bahan ajar mencakup: (a) kesesuaian penggunaan bahasa dengan tingkat berpikir peserta didik, (b) penggunaan bahasa komunikatif dalam materi bahan ajar, (c) ketepatan tata bahasa dan ejaan, (d) penggunaan bahasa Indonesia yang sederhana dan lugas, (e) penggunaan bahasa komunikatif dalam petunjuk dan latihan, dan (f) penggunaan bahasa yang santun. Validasi kebahasaan yang dilakukan menghasilkan persentase sebagaimana pada Tabel 3 .

Berdasarkan Tabel 3, diketahui bahwa jumlah jawaban per aspek penilaian $\left(\sum \mathrm{x}\right)$ adalah 46, sedangkan jumlah skor maksimal per aspek penilaian adalah 48. Persentase kelayakan produk sebesar 95,8 \%. Rata-rata validasi kebahasaan bahan ajar sebesar $95,8 \%$. Persentase tersebut menunjukkan bahwa kualifikasi bahan ajar dari segi kebahasaan berkategori sangat layak.

Tabel 3. Hasil Validitas Kebahasaan Bahan Ajar

\begin{tabular}{|c|c|c|c|c|c|c|}
\hline \multirow[t]{2}{*}{ No } & \multirow[t]{2}{*}{ Aspek Penilaian } & \multicolumn{2}{|c|}{ Validator } & \multirow{2}{*}{$X$} & \multirow{2}{*}{$X i$} & \multirow{2}{*}{$\mathrm{Pi}$} \\
\hline & & VA2 & $\mathbf{V P}$ & & & \\
\hline 1 & Kesesuaian Bahasa dengan Tingkat Berpikir Siswa & 4 & 4 & 8 & 8 & $100 \%$ \\
\hline 2 & Komunikatif dalam Penyajian Materi & 3 & 4 & 7 & 8 & $87,5 \%$ \\
\hline 3 & Ketepatan Tata Bahasa dan Ejaan & 4 & 4 & 8 & 8 & $100 \%$ \\
\hline 4 & $\begin{array}{l}\text { Penggunaan bahasa yang sederhana dan lugas } \\
\text { dalam penyampaian materi }\end{array}$ & 3 & 4 & 7 & 8 & $87,5 \%$ \\
\hline 5 & Komunikatif dalam Petunjuk dan Latihan & 4 & 4 & 8 & 8 & $100 \%$ \\
\hline 6 & Penggunaan bahasa yang santun dan runtut. & 4 & 4 & 8 & 8 & $100 \%$ \\
\hline & Jumlah $\left(\sum\right)$ & & & 46 & 48 & \\
\hline
\end{tabular}


Tabel 4. Validitas Kegrafikaan Bahan Ajar

\begin{tabular}{llccccc}
\hline No & Aspek Penilaian & VA4 & VP & $X$ & $x i$ & Pi \\
\hline 1 & Pemilihan Judul & 4 & 4 & 8 & 8 & $100 \%$ \\
2 & Format Tampilan & 8 & 8 & 16 & 16 & $100 \%$ \\
3 & Kemenarikan Sampul & 8 & 8 & 16 & 16 & $100 \%$ \\
4 & Relevansi Gambar dan Ilustrasi & 8 & 8 & 16 & 16 & $100 \%$ \\
5 & Gaya Cetak dan Ukuran Huruf & 4 & 4 & 8 & 8 & $100 \%$ \\
6 & Keselarasan Warna & 4 & 4 & 8 & 8 & $100 \%$ \\
\hline & Jumlah $\left(\sum\right)$ & & 72 & 72 & \\
\hline
\end{tabular}

\section{Validitas Kegrafikaan Bahan Ajar}

Validitas kegrafikaan dilakukan oleh validator ahli kegrafikaan (VA4) dan validator praktisi (VP). Validasi kegrafikaan bahan ajar mencakup: (a) pemilihan judul bahan ajar, (b) format tampilan, (c) kemenarikan sampul, (d) relevansi gambar dan ilustrasi, (e) gaya cetak dan ukuran huruf, (f) keselarasan warna, dan (g) desain isi modul. Validasi kegrafikaan ditunjukkan pada Tabel 4.

Berdasarkan Tabel 4., diketahui bahwa penilaian per aspek penilaian $\left(\sum \mathrm{x}\right)$ adalah 72 , sedangkan jumlah skor maksimal per aspek penilaian adalah 72. Persentase kelayakan aspek kebahasaan bahan ajar sebesar $100 \%$. Kualifikasi bahan ajar dari segi kegrafikaan berkategori sangat layak.

Secara umum, persentase rata-rata keseluruhan validitas bahan ajar ebesar $91,7 \%$. Persentase tersebut menunjukkan bahwa kualifikasi bahan ajar berdasarkan isi, konstruk, penyajian, kebahasaan, dan kegrafikaan berkategori sangat layak.

\section{Penerapan Modul}

Bahan ajar yang sudah divalidasi, diuji coba pada subjek penelitian, yaitu siswa kelas VII Sains SMP Nuris Jember. Kegiatan uji coba ini untuk mengetahui respon penggunaan bahan ajar dengan cara melaksanakan kegiatan belajar mengajar. Kegiatan belajar mengajar dilakukan oleh peneliti sebagai guru model didampingi guru Bahasa Indonesia kelas VII sebagai observer untuk mengamati aktivitas siswa dan guru selama proses pembelajaran berlangsung.

Pertemuan pertama mengajarkan materi yang terdapat dalam pembelajaran unit 1 terkait memahami struktur dan kaidah kebahasaan teks prosedur. Siswa berjumlah 25 anak dan seluruh siswa mendapat modul suplemen pembelajaran yang diuji coba. Setelah kegiatan pembelajaran selesai, siswa mencoba mengerjakan latihan untuk memantapkan pemahaman dan merespon refleksi yang terdapat di dalam modul siswa.

Penilaian observer pada penerapan modul mencakup: (a) prapembelajaran; berisi persiapan pelaksanaan pembelajaran, (b) kegiatan pembelajaran; berisi cara guru mengomunikasikan atau menyampaikan pembelajaran dan proses pembelajaran siswa secara keseluruhan, (c) penutup; berisi refleksi dan simpulan dari proses pembelajaran yang dilaksanakan, serta informasi pembelajaran berikutnya. Nilai maksimal untuk prapembelajaran adalah 10. Nilai maksimal untuk kegiatan pembelajaran 105. Nilai maksimal untuk kegiatan penutup 15 . Nilai maksimal untuk keseluruhan adalah 120. Tabel 5 menunjukkan hasil penerapan modul pertemuan pertama.

\section{Tabel 5. Penerapan Modul Pertemuan Pertama}

\begin{tabular}{clc}
\hline No & Aspek yang Diamati & Skor \\
\hline 1 & Prapembelajaran & 7 \\
2 & Kegiatan Pembelajaran & 92 \\
3 & Penutup & 15 \\
\hline & Jumlah & 114 \\
\hline
\end{tabular}

Table 5 menunjukkan bahwa skor nilai per aspek yang diamati observer secara keseluruhan adalah 114, sedangkan jumlah skor maksimal per aspek yang diamati adalah 120. Berdasarkan hasil observasi pertemuan pertama diketahui bahwa persentase penerapan bahan ajar sebesar $95 \%$. Sesuai dengan kriteria yang telah ditetapkan, persentase tersebut menunjukkan penggunaan bahan ajar berkategori layak pada pertemuan pertama. Guru selaku observer memberikan catatan bahwa penyampaian materi menggunakan bahan ajar sangat membantu siswa untuk memahami teks prosedur dengan mudah dan menarik. 
Pertemuan kedua dilakukan untuk pembelajaran unit dua terkait menulis teks prosedur. Setelah kegiatan pembelajaran selesai, siswa melakukan tiga hal, yakni: (1) mengerjakan uji kompetensi, (2) merespon kolom refleksi yang terdapat di dalam modul, dan (3) mencari ide terkait tata cara ibadah yang dapat dijadikan teks prosedur. Tabel 6 berisi menunjukkan penerapan bahan ajar pada pertemuan kedua.

Tabel 6. Penerapan Modul Pertemuan Kedua

\begin{tabular}{clc}
\hline No & Aspek yang Diamati & Skor \\
\hline 1 & Pra Pembelajaran & 9 \\
2 & Kegiatan Pembelajaran & 94 \\
3 & Penutup & 15 \\
\hline \multicolumn{2}{c}{ Jumlah } & 118 \\
\hline
\end{tabular}

Tabel 6 menunjukkan bahwa skor nilai per aspek yang diamati dari observer secara keseluruhan adalah 118, sedangkan jumlah skor maksimal per aspek yang diamati adalah 120. Berdasarkan hasil penerapan bahan ajar pertemuan kedua diketahui bahwa persentase penerapan bahan ajar sebesar $98 \%$. Sesuai dengan kriteria yang telah ditetapkan, persentase tersebut menunjukkan penggunaan bahan ajar berkategori layak. Selain itu, persentase hasil observasi pertemuan kedua lebih baik dibanding pertemuan pertama.

\section{Respon Penggunaan Bahan Ajar}

Penilaian respon siswa terhadap penggunaan bahan ajar diperoleh dengan cara menyebarkan lembar observasi uji coba kepada siswa. Penyebaran lembar uji coba bahan ajar dilaksanakan setelah kegiatan pembelajaran kedua kepada 25 siswa yang terdiri atas 6 siswa laki-laki dan 19 siswa perempuan. Hasil respon siswa ditunjukkan pada Tabel 5.

Tabel 5. Respon Siswa terhadap Bahan Ajar

\begin{tabular}{clccc}
\hline No & Aspek Penilaian & $X$ & $X i$ & $\mathrm{P} i$ \\
\hline 1 & $\begin{array}{l}\text { Isi dan konstruk } \\
\text { Bahan Ajar }\end{array}$ & 272 & 300 & $90,7 \%$ \\
2 & $\begin{array}{l}\text { Sistematika } \\
\text { Penyajian Bahan } \\
\text { Ajar }\end{array}$ & 183 & 200 & $91,5 \%$ \\
3 & $\begin{array}{l}\text { Kebahasaan } \\
\text { Bahan Ajar } \\
4\end{array}$ & 177 & 200 & $88,5 \%$ \\
& $\begin{array}{l}\text { Kegrafikaan } \\
\text { Bahan Ajar }\end{array}$ & 347 & 400 & $86,7 \%$ \\
\hline & Jumlah $\left(\sum\right)$ & 979 & 1100 & $89 \%$ \\
\hline
\end{tabular}

Berdasarkan Tabel 5, jumlah jawaban 25 subjek uji coba (siswa) keseluruhan aspek penilaian $\left(\sum x\right)$ adalah 979, sedangkan jumlah skor maksimal adalah 1100. Persentase kelayakan bahan ajar sebesar 89\%. Sesuai dengan kriteria yang telah ditetapkan, persentase tersebut menunjukkan kualifikasi bahan ajar berkategori sangat layak dari sudut pandang pengguna bahan ajar atau siswa kelas VII SMP.

\section{Pembahasan}

Penelitian pengembangan yang dilakukan menghasilkan produk bahan ajar berupa modul. Berdasarkan uji validasi dan respon pengguna modul layak diimplementasikan dengan persentase kelayakan sebesar 91,7\%. Hasil tersebut menunjukkan bahwa bahan ajar ini dapat digunakan pada pembelajaran menulis teks prosedur kelas VII SMP di lingkungan pesantren.

Modul ini merupakan suplemen untuk bahan ajar yang disediakan oleh pemerintah. Keunggulan modul ini adalah penggunaan teks pemodelan berupa teks prosedur yang dikonstruksi dari teks tata cara ibadah pada Kitab Safinatun Najah, seperti teks berjudul Tata Cara Wudu, Tata Cara Memandikan Jenazah, dan berbagai teks lainnya. Siswa mempelajari Kitab Safinatun $\mathrm{Na}$ jah pada madrasah diniyah atau pelajaran muatan lokal Fikih, kemudian pelajaran Fikih tersebut dijadikan sumber materi ajar dalam pembelajaran Bahasa Indonesia pada materi menulis teks prosedur. Hasil penelitian ini sejalan dengan temuan Yasin (2017) yang mengungkapkan bahwa Kitab Safinatun Najah adalah sumber bahan ajar fikih yang efektif digunakan pada pembelajaran.

Modul yang dikembangkan melalui penelitian ini memiliki keunggulan pada topik-topik yang kontekstual dengan lingkungan siswa. Proses akhir dari pembelajaran menulis teks prosedur pada modul ini adalah menghasilkan produk teks prosedur yang dibuat oleh siswa. Selain itu, modul juga terintegrasi dengan mata pelajaran yang lain, yakni fikih. Selain belajar materi bahasa Indonesia, siswa juga belajar fikih. Desain modul demikian sejalan dengan tujuan pembelajaran Bahasa Indonesia sebagai penghela ilmu pengetahuan yang menjadi penciri dalam Kurikulum 2013. Pada proses pembelajaran menulis teks prosedur ditekankan kebermakanaan pembelajaran dengan menyesuaikan lingkungan atau kontekstual. Sejalan dengan hal tersebut Abidin (2012:182) menjelaskan bahwa menulis merupa- 
kan proses untuk mengemukakan pendapat, menyampaikan pesan dalam dimensi sosial untuk tujuan tertentu. Menulis juga dapat ditafsirkan sebagai aktivitas membuat makna yang berhubungan dengan pengembangan kemampuan individu dalam memahami konteks sosial budaya tempat tulisan tersebut dibuat.

Modul menulis teks prosedur berbasis $\mathrm{Ki}$ tab Safinatun Najah ini memiliki perbedaan dengan modul lainnya. Melalui modul yang dihasilkan, siswa dapat menulis teks prosedur yang bersumber dari ide-ide kegiatan ibadah pada Kitab Safinatun Najah. Proses menulis melalui bahan ajar yang dikembangkan disesuaikan konteks lingkungan pesantren. Wekke (2014) menyebutkan bahwa siswa yang berada di bawah naungan pondok pesantren dituntut untuk memliki kemampuan menyampaikan ilmu keagamaan kepada orang lain. Dengan demikian, modul menulis teks prosedur berbasis Kitab Safinatun Najah ini memenuhi kriteria tujuan pembelajaran di lingkungan pesantren dan pencapaian kompetensi pembelajaran Bahasa Indonesia.

Selain memiliki keunggulan, bahan ajar me-nulis teks prosedur ini memiliki kelemahan. Pembelajaran berbasis Kitab Safinatun Najah hanya terbatas pada sekolah di bawah naungan pondok pesantren sehingga tidak semua sekolah dapat menggunakan modul suplemen ini. Modul ini juga masih terbatas pada materi menulis teks prosedur sehingga perlu diadakan pengembangan pada teks lainnya. Penelitian juga masih terbatas pada tahap develop sehingga perlu ditindaklanuti pada tahap disseminate.

\section{DAFTAR PUS TAKA}

Abidin, Yunus. 2012. Pembelajaran Bahasa Indonesia Berbasis Pendidikan Karakter. Bandung: Refika Aditama.

Al'aliyah, Orina Isnaeni. 2017. Pengembangan Media Video Slide Berbasis Audio Visual dalam Pembelajaran Menulis Teks Prosedur Siswa Kelas VII SMP Negeri 21 Surabaya Tahun Pelajaran 2016/2017. Skripsi. Surabaya: Program Studi Bahasa dan Sastra Indonesia Fakultas Bahasa dan Seni Universitas Negeri Surabaya.

Arikunto, Suharsimi. 2002. Prosedur Penelitian Suatu Pendekatan Praktek Edisi Revisi VI. Yogyakarta: Rineka Cipta.

BSNP. 2007. Standar Penilaian Buku Teks Pelajaran. Jakarta: Badan Standar Nasional Pendidikan.

Depdiknas. 2008. Panduan Pengembangan Bahan Ajar. Jakarta: Direktorat Pembinaan Sekolah Menengah Pertama.

\section{PENUTUP}

Berdasarkan penelitian yang telah dilakukan dapat disimpulkan sebagai berikut. (1) Bahan ajar menulis teks prosedur berbasis kitab Safinatun Najah yang dihasilkan berbentuk modul dengan sistematika yang mencakup bagian pendahuluan, bagian inti, dan bagian penutup. (2) Modul menulis teks prosedur yang dihasilkan melalui penelitian dan pengembangan ini memiliki tingkat validitas yang sangat tinggi pada keempat aspek, yakni validitas bahan ajar memperoleh hasil kelayakan dengan rata-rata persentase $91,7 \%$. (3) Penerapan bahan ajar menulis teks prosedur berbasis Kitab Safinatun Najah di kelas VII SMP/MTS di lingkungan pesantren menunjukkan bahwa modul sangat layak digunakan dengan skor 95\% dan 98\%. (4) Respon siswa kelas VII SMP Nuris terhadap bahan ajar menulis teks prosedur berbasis Kitab Safinatun Najah menunjukkan bahwa modul sangat layak untuk diterapkan dengan rata-rata persentase $89 \%$. Berdasarkan hasil tersebut bahan ajar yang dikembangkan layak untuk diterapkan pada pembelajaran.

\section{UCAPAN TERIMA KASIH}

Penulis menyampaikan ucapan terima kasih kepada mitra bestari (reviewers) yang telah memberikan saran, kritik, dan rekomendasi untuk perbaikan artikel ini. Ucapan terima kasih juga disampaikan kepada validator, guru, dan siswa yang telah berpartisipasi dalam pelaksanaan uji coba produk bahan ajar.

Hasan, N. M., dan Supriyanto, Arie. 2016. Model Pembelajaran Berbasis Pondok Pesantren dalam Membentuk Karakter Siswa. Jurnal Transformasi. 12 (1): 51-60.

Kurniasari, Indah. 2015. Pengembangan Modul Menulis Teks Prosedur Kompleks untuk Siswa SMA Kelas X. Skripsi. Malang: Jurusan Sastra Indonesia Fakultas Sastra Universitas Negeri Malang.

Mahsun. 2014. Teks dalam Pembelajaran Bahasa Indonesia Kurikulum 2013. Jakarta: Raja Grafindo Persada.

Permendikbud. 2016. Peraturan Menteri Pendidikan dan Kebudayaan Nomor 24 Tahun 2016 tentang Kerangka Dasar dan Struktur Kurikulum Sekolah Menengah Pertama/Madrasah Tsanawiyah. Jakarta: Kementrian Pendidikan dan Kebuday aan.

Rapi Tang, M., Jufri, Sultan. 2015. Pengembangan Bahan Ajar Cerita Fiksi Berbasis Wacana Budaya di Sekolah Dasar. Pendidikan dan Pembelajaran, 22(2): 169-175. 
118 RETORIKA: Jurnal Bahasa, Sastra, dan Pengajarannya Volume 11, Nomor 2, Agustus 2018, hlm. 108-118

Saleh, M. dan Sultan. 2015. Pengembangan Bahan Ajar Bahasa Indonesia Berbasis Kurikulum 2013 yang Mengintegrasikan Karakter Bangsa di SMP. Pendidikan dan Pembelajaran, 22(2): 117-129.

Sorraya, Artifa. 2014. Pengembangan Bahan Ajar Teks Prosedur Kompleks dalam Pembelajaran Bahasa Indonesia untuk Kelas X SMK. NOSI, 2(2): 21-25.

Susilo, A., Siswandari, dan Bandi. 2016. Pengembangan Modul Berbasis Saintifik untuk Meningkatkan Kemampuan Mencipta Siswa dalam Proses Pembelajaran Akuntansi Siswa Kelas XII SMAN Sloghohimo 2014. Jurnal Pen-didikan Ilmu Sosial. 26 (1) $50-56$

Thiagarajan, S., Semmel, D. S and Semmel, M. I. 1974. Instructional Development for Training Teac- hers of Exceptional Children. Minnesota: Leadership Training Institute/Special Education, University of Minnesota.

Trianto, 2008. Mendesain Pembelajaran Kontekstual (Contextual Teaching and Learning) di Kelas. Jakarta: Cerdas Pustaka Publisher.

Wekke, Ismail, Suwardi. 2014. Tradisi Pesantren da-lam Konstruksi Kurikulum Bahasa Arab di Lembaga Pendidikan Minoritas Muslim Papua Barat. Jurnal Karsa, 22 (1): 22-39.

Yasin, Asep Badri. 2017. Pengaruh Pembelajaran Kitab Safinatun Naiah terhadap Prestasi Siswa pada Mata Pelajaran Fiqih: Studi MA Daarul Falah Ciloang Kota Serang. Tesis. Banten: UIN Banten. 